http://journal.ummat.ac.id/index.php/imk e-ISSN 2685-1857 | p-ISSN 2339-0557

Crossref: https://doi.org/10.31764/imk

\title{
LEGAL PROTECTION FOR SKINCARE USERS THAT DOES NOT HAVE A PRODUCTION LICENSE REVIEW OF THE CONSUMER PROTECTION ACT
}

\author{
Siska Diana Sari ${ }^{1}$ \\ Universitas PGRI Madiun \\ Email: siskadianasari@ymail.com \\ Arief Budiono ${ }^{2}$ \\ Universitas PGRI Madiun \\ Corrisponding Authors Email: areevahims@gmail.com \\ Dita Ajeng Yulianie ${ }^{3}$ \\ Muhammadiyah University of Ponorogo \\ Email:ditaaajeng@gmail.com \\ DOI: https://doi.org/10.31764/jmk.v11i2.3256
}

Received: Agt 18, 2020, Accepted: Sept 16, 2020 /Published: Okt 31, 2020

\begin{abstract}
This article discusses consumer protection against skincare users. Skincare is a series of products that support skin health, improve appearance and maintain skin condition. Skin care products have different ingredients that skin needs. Skincare is a number of daily routine items carried out by a number of women, to achieve the desired results. It is this factor that attracts women to look for safe but effective skin care products in making white, eliminating dark spots, eliminating acne to blackheads in the female skin area. However, there are a number of individuals from skin care manufacturers making skin care with ingredients that are unsafe for skin health. Using empirical legal research method that is research that serves to look at the law in a clear sense and examine the role of law in society. Sociological law research, because it interacts with the community. This method is taken based on field facts. As for the results of this study, that a number of individuals from skin care manufacturers make products using ingredients that are not safe for the health of consumers' skin. Consumer protection is taken as any action and under the law, taken by the government with the aim of protecting consumers and obtaining legal certainty. To protect consumer rights, governments and consumers must play an active role, because businesses or manufacturers have many ways to trick consumers.
\end{abstract}

Keywords: consumer protection; skin care products.

Artikel ini membahas perlindungan konsumen terhadap pengguna skincare. Skincare adalah serangkaian produk yang mendukung kesehatan kulit, meningkatkan penampilan dan menjaga kondisi kulit. Produk perawatan kulit memiliki bahan berbeda yang dibutuhkan kulit. Skincare adalah sejumlah item rutin harian yang dilakukan oleh sejumlah wanita, 
untuk mencapai hasil yang diinginkan. Faktor inilah yang menarik wanita untuk mencari produk perawatan kulit yang aman namun efektif dalam membuat putih, menghilangkan bintik-bintik gelap, menghilangkan jerawat hingga komedo di area kulit wanita. Namun, ada sejumlah individu dari produsen perawatan kulit membuat perawatan kulit dengan bahan-bahan yang tidak aman untuk kesehatan kulit. Menggunakan metode penelitian hukum empiris yaitu penelitian yang berfungsi untuk memandang hukum dalam arti yang jelas dan meneliti peran hukum dalam masyarakat. Penelitian hukum sosiologis, karena pihaknya berinteraksi dengan masyarakat. Metode ini diambil berdasarkan fakta lapangan. Adapun hasil penelitian ini, bahwa sejumlah individu dari produsen perawatan kulit membuat produk menggunakan bahan-bahan yang tidak aman untuk kesehatan kulit konsumen. Perlindungan konsumen diambil sebagai tindakan apa pun dan berdasarkan undangundang, yang diambil oleh pemerintah dengan tujuan melindungi konsumen dan mendapatkan kepastian hukum. Untuk melindungi hak konsumen, pemerintah dan konsumen harus berperan aktif, karena bisnis atau produsen memiliki banyak cara untuk mengelabui konsumen.

Kata kunci: perlindungan konsumen; produk perawatan kulit.

\section{INTRODUCTION}

Today, women's demands to appear perfect have become things which is mandatory. From the fashion style to the skincare he uses, he must pay close attention. Having white, shine-free skin is the desire of every woman, especially in Indonesia.

This factor is what attracts women to look for skincare products that are safe but effective in making white, removing black spots, removing acne to blackheads in the area of the woman's skin. However, this factor is used by a number of individuals from the skincare producers to make skincare with ingredients that are not safe for the skin health of consumers who use the skincare products. Its attractiveness also lures consumers to buy it, because the price is cheap, can be purchased at any time, and the ease of online transactions is a very factor for consumers to buy it.

Consumers have not realized that with cheap prices and the lure of having instant white skin is the goal of the skincare manufacturer, the 
products sold can have a bad impact on skin health. Therefore, the position of consumers is weak in terms of unfair consumer protection to protect consumer rights. ${ }^{1}$

Protection of consumers is increasingly important in this globalization era, because the development of science and technology is the main factor and the effectiveness of producers of the products or services they produce in achieving business marketing targets. In terms of pursuing and achieving these targets, ultimately it is still consumers who will definitely get the negative impact of these products. ${ }^{2}$ Protection of consumers as well as article 4 letter a of Law Number 8 of 1999 About Consumer Protection has the right to obtain safety, security, and comfort in enjoying the services Offered. ${ }^{3}$

In Indonesia, there is a regulation to create a product or a number of pharmaceuticals containing chemical compounds, including having a license from the Food and Drug Supervisory Agency (BPOM) or a halal test from the Indonesian Ulema Council (MUI). So if one of the licenses is not registered, then the product can be withdrawn from the marketing license because it violates the law.

"The Food and Drug Administration (BPOM) in 2018 destroyed confiscated products reaching 2,045 items. This illegal product is the result of surveillance and prosecution in West Java". These items are obtained from online sales facilities. Of the 2045 items destroyed, around 50\% of cosmetics are illegal. ${ }^{4}$

\footnotetext{
1 Ahmadi Miru, 2011, Prinsip-Prinsip Perlindungan Hukum bagi Konsumen di Indonesia, PT. Raja Grafindo Persada, Jakarta, Hal 1.

2 Happy Susanto, 2008, Hak-Hak Konsumen Jika Dirugikan, Visimedia, Jakarta, Hal. 39.

3 Yanto, E., Imawanto, I., \& Yuliani, T. 2020. "Perlindungan Hukum Konsumen Jasa Parkir Ditinjau Dari Hukum Positif". Media Keadilan: Jurnal Ilmu Hukum. https://doi.org/10.31764/jmk.v11i1.2264, Volume 11 nomor 1, Hal 121.

4 BPOM RI Musnahkan Barang Ilegal Senilai Miliaran Rupiah, http://www.tribunnews.com/regional/2018/12/20/bpom-ri-musnahkan-barang-ilegal-senilai-miliaran-rupiah diakses pada 7 April 2019.
} 


\section{METHODOLOGY}

This paper uses empirical legal research methods. The empirical legal research method is a research method that functions to view law in a clear sense and examine the role of law in society ${ }^{5}$. This research method is categorized as sociological legal research because it interacts with the community. This method is also taken based on field facts that occur in community problems ${ }^{6}$.

\section{DISCUSSION}

1. Definition of Skincare

Skincare is a series of products that support skin health, improve appearance and maintain skin condition. Skincare products have different materials that the skin needs. Skincare is a number of daily routine items that are carried out by a number of women, to achieve the desired results by women. This skincare consists of a number of products and treatments using chemicals or electric devices that are carried out in a number of beauty clinics through procedures, and are supervised by a specialist or specialist in skin and genitalia.

2. Skincare licensing according to Ministry of Health Regulation No.1175/Menkes/Per/VIII/2010 concerning Cosmetics Production Permit

Basically all products produced by a number of companies must have a license, in this case skincare that is produced before marketing must have a production permit by registering with BPOM and then the directorate general of the Indonesian Ministry of Health. Does the skincare contain dangerous chemicals or not.

\footnotetext{
${ }^{5}$ Rianto Adi. 2005. Metode Penelitian Sosial dan Hukum. Jakarta: Granit

6 Peter Mahmud Marzuki. 2010. Penelitian Hukum. Cetakan Kedua. Jakarta: Kencana.
} 
In Article 9 Pemenkes No.1175 of 2010 concerning Cosmetics Production Permit, the requirements that must be fulfilled include: ${ }^{7}$
a. Have a pharmacist
b. Has a number of facilities for the production of these products
c. Has a laboratory
d. Has a number of pharmaceutical personnel.

3. Patient protection according to Law No.36 of 2009 on Health

This Law contains matters concerning the provisionsmedical personnel, medical facilities in hospitals, technology and use of technology, including the rights of patients. For example, the protection of patients with plastic surgery cases, so the hospital, medical personnel are obliged to keep the identity and actions taken by medical personnel against patients to protect the privacy of these patients.

Also applies to the management of doctor's practice malls carried out by patients, according to article 58 of Law No.36 of 2009 concerning Health, namely the patient has the right to claim compensation for the wrongdoing of the medical personnel because he neglected to treat the patient, and caused both material and physical harm to the patient. ${ }^{8}$

4. Consumer protection according to Law No.8 of 1999 on Consumer Protection

Consumer protection is any action taken by the government with the aim of protecting consumers and obtaining legal certainty to protect consumer rights because business actors or producers have more and more ways to trick consumers, so that their goods/services are bought or used by many consumers. Consumer is someone who uses goods or services to meet their needs.

\footnotetext{
7 Peraturan Kementrian Kesehatan No.1175/Menkes/Per/VIII/2010 tentang Izin Produksi Kosmetika.

8 Peraturan Perundang-Undangan No.36 tahun 2009 tentang Kesehatan.
} 
In articles 8-17 of Law No.8 of 1999 concerning Consumer Protection, business actors or prosudents are prohibited from:

a. Not in accordance with statutory standards

b. Does not match the content in the net weight

c. Does not match the image being promoted

d. Does not show expiration date

e. Absence of a halal label

f. There is no mention of how to use it

g. Producers are prohibited from selling goods that are damaged. ${ }^{9}$

The description of the article is very clear that as a producer it is prohibited to harm consumers. However, it is still being violated, because one of the factors is so that the goods produced are in high demand.

5. Consumer Protection Law as a Form of State Presence in Protecting Consumers in Indonesia

Consumer protection law is the whole principles and rules that regulate and protect consumers in buying and selling relationships between providers and users in trading relations. According to Prof. Dr. Moctar Kusumaatmadja. Consumer law is the whole of the governing principles and rules. Relationships and problems with the provision and use of goods/services between providers and users in social life.

So, in essence, consumer protection law is a public law that regulates and limits entrepreneurial behavior to protect consumer interests. The behavior referred to is the behavior of unfair competition, monopoly, oligopoly by entrepreneurs, so as to encourage business actors to act honestly and with good intentions as well as prevention of business activity behavior that has a negative impact on society.

\footnotetext{
9 Peraturan Perundang-Undangan No.8 tahun 1999 tentang Perlindungan Konsumen
} 
In an attempt to elaborate on the concept of the relationship between producers and consumers which is an absolute authority, the suspicion not from the Consumer Protection Law is that producers and consumers need each other, ${ }^{10}$ production is meaningless if no one consumes and vice versa so that this law is intended so that both parties play their roles fairly (fair).

The consumer protection law is a manifestation of the state constitution, namely the 1945 Constitution so that its implementation and protection must be taken seriously by the state, history has proven that capitalists and neolibs, who are entrepreneurs, are able to do anything to gain profits, such as the basic principle of economic law, namely "by sacrifice the smallest amount to get the maximum benefit".

The desire of business actors to reap the maximum benefits can be encouraging business actors to cheat, whether in the form of promotions that can attract consumers, fraudulent sales methods, and application of purchase agreements that tend to be more pro-business actors and can harm consumers.

The tendency of business actors to cheat makes the position of consumers and business actors unbalanced and places consumers in a weak position, one of the things behind this is the low level of pengetconsumer awareness of their rights, another thing is the lack of knowledge about the production process and consumer bargaining processes that are weaker economically.

Losses experienced by consumers may not always occur due to fraudulent acts by business actors, but also occur from ignorance and the inability of consumers to choose a product.ng has been declared

\footnotetext{
10 Yusuf Shofie. 2010. Tanggungjawab Pidana Korporasi Dalam Tindak Pidana Perlindungan Konsumen Di Indonesia: Analisis Tentang Perkara-Perkara Tindak Perlindungan Konsumen. Pendidikan Doktor Ilmu Hukum Universitas Indonesia.
} 
safe by the state so that the phenomenon that occurs in society is that the people themselves underestimate the supervisory bodies or state organizations and institutions that are empowered to monitor the entry of consumer goods so that there is a bias between state administrators and the public as the subject it protects.

Based on the Indonesian constitution, namely the fourth paragraph of the 1945 Constitution, the main objective of the state is to create a just and prosperous society that is balanced between material and spiritual, in an era of economic democracy based on Pancasila, it must be a parameter and benchmark in carrying out all life activities including activities in business world.

The demands of competition in the era of globalization must be a trigger for national economic development and must be able to spur the growth of the world businesses so that they can produce goods and services that not only participate in building the community's economy but also participate in increasing state tax revenue.

Era globalization which is marked by, among other things, the opening of the Asian economic community which is a sign that trade boundaries between countries are being eliminated. Being a responsibility for the state to be present and protect its people from this condition, the Consumer Protection Law as a government effort to improve the welfare of the community while protecting consumers and their rights is in accordance with article 3 of the Consumer Protection Law.

A Consumers in consuming goods and services must be able to distinguish whether a consumption product is legal or not because from there it can be ascertained whether an item is of guaranteed quality or not. Therefore, a consumer must be intelligent so that he does not become a victim in the circulation of illegal consumption products. 
In order to be a smart consumer, a consumer must first understand his rights. In Article 4 of the Consumer Protection Law, it is stated that the rights of consumers are: the right to goods and/or services, the right to choose goods, and/services and the latter to obtain these goods and/services in accordance with the exchange rate and conditions and guarantees promised. If there is only one of these rights that is not fulfilled, the consumer can sue the producer because it does not heed the rights of the consumer.

Public awareness of the urgency of consumer protection law itself is when society as consumers knows and Understanding that the capitalists, who in fact as producers are able or can do anything just to gain profits even though the product is below the standard for consumption, this is the basis for the movement of countries around the world to create special institutions that aim to protect consumers.

In Indonesia it self, the government has created a special institution to protect consumers which is known as the BPKN (National Consumer Protection Agency). The task of which is reflected in its name, namely protecting consumers and their rights, this institution was founded in 2001.

But on the other hand, we can still see that people still use illegal products that do not even pass the standard feasibility test for consumer goods so that these products are detrimental to themselves. This research intends to describe people's behavior and their level of understanding of the law consumer protection ${ }^{11}$.

Nowadays, women's demands to appear perfect have become mandatory. From the fashion style to the skincare he uses, he must pay close attention. Having white, shine-free skin is the desire of every

11 Husein Kerbala. 1993. Segi-segi Etis dan Yuridis Informed Consent. Jakarta: Pustaka Sinar Harapan 
woman, especially in Indonesia, this factor is what attracts women to look for skincare products that are safe but effective in making white, removing black spots, removing acne to blackheads in the area of the woman's skin. However, this factor is used by skincare producers to make skincare with ingredients that are not safe for the skin health of consumers who use these skincare products.

Basically there is a relationship between business actors and consumers, the relationship in question is in the form of rights and obligations between producers and consumers as regulated in Law No. 8 of 1999. There are 9 points of consumer rights discussed in this law which aim to protect the interests of consumers themselves, but in practice many shops or minimarkets that sell skincare products do not get official permission from BPOM ${ }^{12}$.

Licensing of a product by consumer protection agencies is not only to enforce consumer protection laws but also to maintain the safety of consumers who use these products, because it is very possible for a product that does not get permission from BPOM to have dangerous content in it.

Attractive packaging and Well-known brands are not a guarantee that these products are safe to use, what else is based on the current development where online shops are mushrooming and everyone can become producers without clear specifications causing an opportunity to run a business illegally ${ }^{13}$.

As happened in the case of Derma Skincarenamely a skincare product that does not have a permit from the BPOM, but is widely

12 Siska Diana Sari. 2016. Protection Of Citizen's Constitutional Rights In The Health Care Beauty Clinic In The Context Of Welfare State In Indonesia. Proceeding International Conference and Call for Papers (ICCP) UNS Theme "Law and Sustainable Development amongst Developed and Developing Countries". Surakarta: Faculty of Law UNS.

13 A.Z. Nasution. 1999. Hukum Perlindungan Konsumen. Jakarta: Pustaka Sinar Harapan. 
known by the public and is even promoted by famous artists such as Via Vallen and Nella Kharisma. The existence of products like this is definitely against the Consumer Protection Law. Because it does not provide a security guarantee for its users.

The use of hazardous ingredients in skincare products is a latent danger for its users due to the frequent use of skincare in the daily lives of consumers, which makes skincare products that contain hazardous materials more dangerous than other illegal products.

Skincarein general, it is a series of skincare products, which function to beautify the skin, solve skin problems and nourish the skin itself. This series of skincare products is called skincare. Product usage ranges skincare This is an activity carried out by women and has become a routine that must be carried out continuously if you want to overcome skin problems such as dry skin problems, prevention of dermatitis, healing or prevention of acne, and blackheads.

Skincareitself has a very close position with cosmetics and dermatology. According to the United States Food Drug and Cosmetics Supervisory Agency, cosmetics are products used to beautify users such as lipstick, powder, etc. Meanwhile, skincare functions more as a medication that is used to cure and treat skin-related problems such as sunscreens and acne creams.

While differences skincare with dermatology is the use of skincare is much simpler when compared to dermatology, which is more medical in scope and is usually performed by beauticians. As explained above, skincare is a series of use of beauty products that are carried out continuously or continuously if the products used actually contain harmful ingredients, it will obviously cause harmful effects to users. Seeing the possible effects of using skincare containing dangerous 
ingredients, it is imperative for the state to pay special attention to these skincare products.

\section{CONCLUSION}

At Indonesia itself the government has created a special institution to protect consumers which is called the BPKN (National Consumer Protection Agency). The task of which is reflected in its name, namely protecting consumers and their rights, this institution was founded in 2001. But on the other hand, we can still see that people still use illegal products that do not even pass the standard feasibility test for consumer goods so that these products are detrimental to themselves. This research intends to describe people's behavior and their level of understanding of the law consumer protection. From the description above, that the role of protecting consumers is not only the government, in this case is BPKN, but also the consumers themselves so that they are smarter and wiser in choosing the products to be used.

\section{REFERENCES}

\section{Buku}

Ahmadi Miru, 2011, Prinsip-Prinsip Perlindungan Hukum bagi Konsumen di Indonesia, PT. Raja Grafindo Persada, Jakarta,

A.Z. Nasution. 1999. Hukum Perlindungan Konsumen. Jakarta: Pustaka Sinar Harapan.

Happy Susanto, 2008, Hak-Hak Konsumen Jika Dirugikan, Visimedia, Jakarta,

Husein Kerbala. 1993. Segi-segi Etis dan Yuridis Informed Consent. Jakarta: Pustaka Sinar Harapan

Rianto Adi. 2005. Metode Penelitian Sosial dan Hukum. Jakarta: Granit 
Peter Mahmud Marzuki. 2010. Penelitian Hukum. Cetakan Kedua. Jakarta: Kencana.

\section{Jurnal, Disertasi}

Yanto, E., Imawanto, I., \& Yuliani, T. 2020. “Perlindungan Hukum Konsumen Jasa Parkir ditinjau dari Hukum Positif". Media Keadilan: Jurnal Ilmu Hukum. https://doi.org/10.31764/jmk.v11i1.2264. Volume 11 nomor 1, April.

Siska Diana Sari. 2016. Protection Of Citizen's Constitutional Rights In The Health Care Beauty Clinic In The Context Of Welfare State In Indonesia. Proceeding International Conference and Call for Papers (ICCP) UNS Theme "Law and Sustainable Development amongst Developed and Developing Countries". Surakarta: Faculty of Law UNS.

Yusuf Shofie. 2010. Tanggungjawab Pidana Korporasi Dalam Tindak Pidana Perlindungan Konsumen Di Indonesia: Analisis Tentang Perkara-Perkara Tindak Perlindungan Konsumen. Pendidikan Doktor Ilmu Hukum Universitas Indonesia

\section{Peraturan Perundang-Undangan}

Peraturan Kementrian Kesehatan No.1175/Menkes/Per/VIII/2010 tentang Izin Produksi Kosmetika.

Peraturan Perundang-Undangan No.36 tahun 2009 tentang Kesehatan.

Peraturan Perundang-Undangan No.8 tahun 1999 tentang Perlindungan Konsumen.

\section{Website}

BPOM RI Musnahkan Barang Ilegal Senilai Miliaran Rupiah, http://www.tribunnews.com/regional/2018/12/20/bpom-rimusnahkan-barang-ilegal-senilai-miliaran-rupiah diakses pada 7 April 2019. 